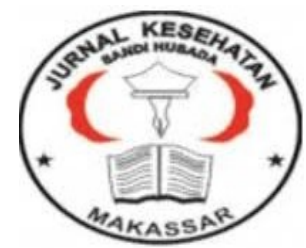

\author{
Jurnal Ilmiah Kesehatan Sandi Husada \\ hhttps://akper-sandikarsa.e-journal.id/JIKSH \\ Vol 11, No, 1, Juni 2020, pp;448-455 \\ p-ISSN: 2354-6093 dan e-ISSN: 2654-4563 \\ DOI: $10.35816 /$ jiskh.v10i2.314
}

ARTIKEL PENELITIAN

\title{
Hubungan Pemberian ASI Eksklusif Dengan Kejadian Stunting Pada Balita
}

Relationship between Exclusive Breastfeeding and Stunting in Toddlers

\begin{abstract}
Sr. Anita Sampe, SJMJ1', Rindani Claurita Toban², Monica Anung Madi ${ }^{3}$
${ }^{123}$ Sekolah Tinggi Ilmu Kesehatan Stella Maris Makssar

Artikel Info

Received; 13 Mei 2020

Revised: 14 Mei 2020

Accepted; 28 Mei 2020

Abstrak

Stunting adalah masalah kurang gizi kronis yang disebabkan oleh asupan gizi yang kurang dalam waktu cukup lama akibat pemberian makanan yang tidak sesuai dengan kebutuhan gizi. Salah satu penyebab stunting pada balita yaitu pemberian ASI eksklusif yang tidak diberikan selama 6 bulan karena ASI sangat dibutuhkan dalam masa pertumbuhan bayi agar kebutuhan gizinya tercukupi. Tujuan Penelitian ini adalah mengetahui hubungan pemberian ASI eksklusif dengan kejadian stunting pada balita. Rancangan penelitian ini menggunakan pendekatan case control study pada 144 responden yang terdiri dari 72 responden kasus dan 72 responden kontrol, responden merupakan orang tua dari balita yang didiagnosis stunting dan non-stunting. Pengambilan sampel menggunakan teknik cluster random sampling. Instrumen yang digunakan berupa kuesioner dan alat ukur mekanik. Hasil penelitian menggunakan uji chi-square dan dilanjutkan menggunakan uji odds ratio. Didapatkan hasil uji chisquare $p=0.000$ (0.000<0.05), hal ini menunjukkan ada hubungan pemberian ASI eksklusif dengan kejadian stunting pada balita. Sedangkan pada uji odds ratio didapatkan nilai $O R=61$ yang artinya balita yang tidak diberikan ASI eksklusif berpeluang 61 kali lipat mengalami stunting dibandingkan balita yang diberi ASI eksklusif. ASI eksklusif dapat mengurai risiko terjadinya stunting.
\end{abstract}

\begin{abstract}
Stunting is a chronic malnutrition problem caused by nutrient intake that is not in accordance with nutritional needs. One of the causes of stunting in children is exclusive breastfeeding is not given during six months because breast milk is needed during in baby's growth period so that the nutritional needs are fulfilled. The purpose of this study was to determine the correlation of exclusive breastfeeding with the incidence of stunting in children. The design of this study was case control study approach on 144 respondents consisting of 72 case respondents and 72 control respondents, respondents were parents of children who were diagnosed with stunting and non-stunting. Sampling of this study using cluster random sampling approach. Instruments is
\end{abstract}


questionnaires and mechanical measuring. The results of this study used chi-square test and odds ratio test. Chi-square test results obtained $p=0.000(0.000<0.05)$, this shows there is correlation of exclusive breastfeeding with the incidence of stunting in children. While in the odds ratio test the value of $R=61$ which means that children who are not exclusively breastfed are 61 times more likely to experience stunting than children who are exclusively breastfed. Exclusive breastfeeding for babies so as to reduce the risk of stunting

\begin{tabular}{lr}
\hline Keyword: & $\begin{array}{r}\text { Coresponden author: } \\
\text { Stunting; }\end{array}$ \\
ASI Eksklusif; & Email: $\begin{array}{c}\text { sranithasimj@gmail.com } \\
\end{array}$ \\
& artikel dengan akses terbuka dibawah lisensi BCC BY NC ND-4.0
\end{tabular}

\section{Pendahuluan}

Stunting adalah masalah kurang gizi kronis yang disebabkan oleh asupan gizi yang kurang dalam waktu cukup lama akibat pemberian makanan yang tidak sesuai dengan kebutuhan gizi. Kekurangan gizi pada usia dini meningkatkan angka kematian bayi dan anak, menyebabkan penderitanya mudah sakit dan memiliki postur tubuh tak maksimal saat dewasa (Millenium Challengga Account Indonesia, 2013).

Stunting terjadi mulai janin masih dalam kandungan dan baru nampak saat anak berusia dua tahun. Stunting pada balita perlu menjadi perhatian khusus karena dapat menghambat perkembangan fisik dan mental anak. Stunting berkaitan dengan peningkatan risiko kesakitan dan kematian serta terhambatnya pertumbuhan kemampuan motorik dan mental juga memiliki risiko terjadinya penurunan kemampuan intelektual, produktivitas, dan peningkatan risiko penyakit degeneratif. Anak stunting juga cenderung lebih rentan terhadap penyakit infeksi, sehingga berisiko mengalami penurunan kualitas belajar di sekolah dan berisiko lebih sering absen, sehingga mengakibatkan kerugian ekonomi jangka panjang bagi Indonesia (Kartikawati, 2011 dalam Indrawati, 2016).

Prevalensi stunting pada balita berdasarkan hasil Riskesdas pada tahun 2013 prevalensi stunting sebanyak 37,2\% dan pada tahun 2018 prevalensi ini menurun secara nasional menjadi 30,8\% (Kemenkes, 2018b). Berdasarkan prevalensi stunting tersebut, kejadian stunting di Indonesia masih menjadi masalah karena prevalensi nasional masih diatas toleransi yang ditetapkan WHO yang hanya 20\% (Kemenkes, 2016). Riskesdas tahun 2018, Provinsi Sulawesi Barat menduduki peringkat kedua angka stunting tertinggi secara nasional sekitar 40\%. Kota Mamasa menduduki urutan kedua se-Sulawesi Barat dan Kecamatan Buntu Malangka menduduki angka kejadian stunting paling tinggi di Kota Mamasa sebesar 49,2\%.

Menurut Unicef Framework faktor penyebab stunting pada balita salah satunya yaitu asupan makanan yang tidak seimbang. Asupan makanan yang tidak seimbang termasuk dalam pemberian ASI eksklusif yang tidak diberikan selama 6 bulan (Wiyogowati, 2012 dalam Fitri, 2018). ASI (Air Susu Ibu) adalah air susu yang dihasilkan oleh ibu dan mengandung zat gizi yang diperlukan oleh bayi untuk kebutuhan dan perkembangan bayi. Bayi hanya diberi ASI saja, tanpa tambahan cairan lain seperti susu formula, air jeruk, madu, air teh, air putih dan tanpa tambahan makanan padat seperti pisang, pepaya, bubur susu, biskuit, bubur nasi dan tim, selama 6 bulan (Mufdlilah, 2017).

Manfaat ASI eksklusif bagi bayi antara lain sebagai nutrisi lengkap, meningkatkan daya tubuh, meningkatkan kecerdasan mental dan emosional yang stabil serta spiritual yang matang diikuti perkembangan sosial yang baik, mudah dicerna dan diserap, memiliki 
komposisi lemak, karbohidrat, kalori, protein dan vitamin, perlindungan penyakit infeksi, perlindungan alergi karena didalam ASI mengandung antibodi, memberikan rangsang intelegensi dan saraf, meningkatkan kesehatan dan kepandaian secara optimal (Mufdlilah, 2017).

Pemberian ASI eksklusif di Indonesia masih jauh dari harapan. Secara nasional, cakupan bayi mendapat ASI eksklusif pada tahun 2017 sebesar 61,33\%. Namun, angka ini belum mencapai dari target cakupan ASI eksklusif yang ditetapkan oleh pemerintah, yaitu $80 \%$ (Kemenkes, 2018c). Di Kota Mamasa khususnya di Kecamatan Buntu Malangka persentase pemberian ASI eksklusif hanya mencapai $17,0 \%$. Hal ini dikarenakan kurangnya tingkat pengetahuan masyarakat mengenai pentingnya pemberian ASI eksklusif, bayi yang sudah diberi makanan tambahan sebelum umur 6 bulan serta kurangnya gizi dari ibu menyusui sehingga produksi ASI menurun.

Menurut penelitian Rohmatun (2014), pada analisis bivariatnya menghasilkan $\mathrm{p}<0.05$ dengan nilai signifikasi 0.45 yang berarti signifikan atau bermakna. Hal ini berarti ada hubungan antara pemberian ASI eksklusif dengan kejadian stunting pada balita di Desa Sidowarno Kecamatan Wonosari Kabupaten Klaten. Penelitian ini Sejalan dengan Indrawati (2016) dimana hasil penelitian menunjukkan bahwa sebagian besar responden yang dalam kategori sangat pendek tidak mendapatkan ASI eksklusif yaitu 10 responden $(7,7 \%)$. Responden dalam kategori pendek sebagian besar mendapatkan ASI eksklusif yaitu 18 responden (13,8\%). Responden yang dalam kategori normal sebagian besar mendapatkan ASI eksklusif yaitu 92 responden (70,8\%). Dimana diperoleh pvalue $=0.000$ $(0.000<0.05)$. Maka disimpulkan bahwa terdapat hubungan pemberian ASI eksklusif dengan kejadian stunting pada balita 2-3 tahun. Sedangkan menurut penelitian Lidia Fitri (2018) ada hubungan yang bermakna antara ASI eksklusif dengan kejadian stunting pada balita di Puskesmas Lima Puluh.

Berdasarkan uraian diatas, menunjukkan bahwa salah satu faktor kejadian stunting yaitu tidak diberikannya ASI eksklusif. Oleh karena itu, sebagai upaya untuk mengetahui dan mamahami bagaimana hubungan pemberian ASI eksklusif yang diberikan oleh ibu kepada balita yang menderita stunting. Maka peneliti tertarik untuk melakukan penelitian dengan tentang hubungan pemberian ASI eksklusif dengan kejadian stunting pada balita di Kecamatan Buntu Malangka Kabupaten Mamasa. Tujuan penelitian untuk mengetahui hubungan pemberian ASI eksklusif dengan kejadian stunting pada balita di Kecamatan Buntu Malangka Kabupaten Mamasa.

\section{Metode}

Penelitian ini menggunakan pendekatan case control study yang merupakan penelitian yang membandingkan kelompok kasus dan kelompok kontrol untuk mengetahui proporsi kejadian berdasarkan riwayat ada tidaknya paparan disebut juga penelitian retrospektif untuk melihat hubungan pemberian ASI eksklusif dengan kejadian stunting pada balita. Tempat penelitian adalah di Kecamatan Buntu Malangka Kabupaten Mamasa, pada bulan Desember 2019-Februari 2020. Populasi dalam penelitian ini dipilih dari 7 desa prioritas stunting di Kecamatan Buntu Malangka Kabupaten Mamasa. Peneliti mengambil 3 desa secara acak yaitu Desa Penatangan, Ranteberang, dan Kebanga. Populasi dalam penelitian ini semua balita di Desa Penatangan, Ranteberang, dan Kebanga yang berjumlah 219 balita.

Data diperoleh dengan melakukan pengukuran TB terhadap anak menggunakan microtoise dan pengisian kuesioner terhadap ibu. Hasil pengukuran TB selanjutnya diolah untuk mendapatkan data status gizi anak dengan menggunakan standar perhitungan z- 
score tinggi badan menurut umur (TB/U) menggunakan tabel antropometri SK Kemenkes, 2010. Data mengenai riwayat pemberian ASI eksklusif diperoleh melalui kuesioner yang diisi oleh ibu balita.

Data dianalisis dengan analisis univariat untuk memperoleh gambaran distribusi frekuensi, analisis bivariat menggunakan uji chi square untuk memperoleh hubungan pemberian ASI eksklusif dengan kejadian stunting pada balita dengan tingkat kemaknaan $\alpha=0,05$. Selanjutnya dilakukan uji Odds Ratio (OR) untuk menentukan seberapa besar hubungan pemberian ASI eksklusif dengan kejadian stunting pada balita.

\section{Hasil dan Pembahasan}

Tabel 1. Analisis Hubungan Pemberian ASI Eksklusif dengan Kejadian Stunting

\begin{tabular}{|c|c|c|c|c|c|c|}
\hline \multirow[t]{3}{*}{ Asi eksklusif } & \multirow{2}{*}{\multicolumn{2}{|c|}{$\begin{array}{c}\text { Kasus } \\
\text { Stunting }\end{array}$}} & \multirow{2}{*}{\multicolumn{2}{|c|}{$\begin{array}{c}\text { Kontrol } \\
\text { Normal }\end{array}$}} & \multirow{3}{*}{$\begin{array}{c}\text { OR } \\
(95 \% \mathrm{CI})\end{array}$} & \multirow[t]{3}{*}{$\mathrm{p}$} \\
\hline & & & & & & \\
\hline & $\mathrm{f}$ & $\%$ & $\mathrm{f}$ & $\%$ & & \\
\hline Tidak & 66 & 91.7 & 11 & 15.3 & $61(21-174)$ & 0.000 \\
\hline Ya & 6 & 8.3 & 61 & 84.7 & & \\
\hline Jumlah & 72 & 100 & 72 & 100 & & \\
\hline
\end{tabular}

Sumber : Data Primer, 2020

Hasil penelitian menunjukkan balita yang tidak diberikan ASI eksklusif dan mengalami stunting sebanyak 66 (91.7\%) responden. Usia balita merupakan masa di mana proses pertumbuhan dan perkembangan terjadi sangat pesat. Usia balita dimulai dari usia 24-60 bulan yang masuk dalam kriteria usia toodler dan pra-sekolah. Pada usia todler (24-30 bulan), biasanya anak sukar atau kurang mau makan, nafsu makan anak sering sekali kali berubah yang mungkin pada hari ini makannya cukup banyak dan pada hari berikutnya makannya sedikit, biasanya anak menyukai jenis makanan tertentu dan anak cepat bosan serta tidak tahan makan sambil duduk dalam waktu yang lama (Diaz, Lusmilasari, \& Madyaningrum, 2017). Sedangkan pada usia pra-sekolah (31-60 bulan), anak telah digolongkan sebagai konsumen aktif yang sudah dapat memilih makanan yang disukainya, namun anak belum dapat memilih sendiri makanan yang baik untuk dikonsumsi (Karyani, Husin, \& Febry, 2012). Pada usia toddler dan pra sekolah ini anak membutuhkan asupan zat gizi yang cukup dalam jumlah dan kualitas yang lebih banyak, karena pada umumnya aktivitas fisik yang cukup tinggi dan masih dalam proses belajar (TNP2K, 2017).

Berdasarkan penelitian yang dilakukan didapatkan nilai OR $=61$ artinya balita yang tidak diberikan ASI eksklusif berpeluang 61 kali lipat mengalami stunting dibandingkan balita yang diberi ASI eksklusif. Kemudian, balita yang tidak diberikan ASI eksklusif memiliki peluang 98\% untuk mengalami stunting.

Rohmatun (2014) menyatakan bahwa stunting lebih banyak ditemukan pada anak yang tidak diberi ASI eksklusif dibandingkan anak yang diberi ASI eksklusif. Berdasarkan kenyataan yang ada dilapangan didapatkan pada kelompok kasus, jumlah responden yang tidak memberikan ASI Eksklusif sebanyak 66 (91.7\%) responden. Sedangkan pada kelompok kontrol, jumlah responden yang tidak memberikan ASI eksklusif sebanyak 11 (15.3\%) responden. Adapun beberapa alasan responden tidak memberikan ASI eksklusif, pada kelompok kasus alasan terbanyak responden tidak memberikan ASI eksklusif yaitu ASI kurang/ASI tidak keluar sebanyak 36 (50.0\%) responden dan jumlah terkecil dengan alasan puting masuk ke dalam sebanyak $2(2.8 \%)$ responden. Sedangkan pada kelompok kontrol, alasan terbanyak tidak memberikan ASI Eksklusif yaitu tidak paham/kurang 
paham dan lain-lain masing-masing sebanyak 4 (5.6\%) responden dan jumlah terkecil dengan alasan kerja disawah/sibuk bekerja sebanyak 1 (1.4\%) responden.

Stunting dapat terjadi sebagai akibat kekurangan gizi terutama pada saat 1000 Hari Pertama Kehidupan (HPK). Buruknya gizi selama kehamilan, masa pertumbuhan dan masa awal kehidupan anak dapat menyebabkan anak menjadi stunting. Pemenuhan gizi yang belum tercukupi baik sejak dalam kandungan hingga bayi lahir dapat menyebabkan terjadinya masalah kesehatan pada balita. Salah satunya panjang lahir bayi yang menggambarkan pertumbuhan linier bayi selama dalam kandungan. Ukuran linier yang rendah biasanya menunjukkan keadaan gizi yang kurang akibat dari kekurangan energi dan protein yang diderita ibu saat mengandung (Kemenkes, 2018a). Berdasarkan hasil penelitian yang diperoleh di Kecamatan Buntu Malangka, balita dengan panjang badan rendah $(<48 \mathrm{~cm})$ paling banyak pada kelompok kasus dibandingkan kelompok kontrol yaitu sebanyak $54(75.0 \%)$ responden.

Hasil penelitian juga menunjukkan terdapat balita yang tidak diberikan ASI eksklusif dan non-stunting sebanyak 11 (15.3\%) responden dimana ada beberapa faktor tidak langsung yang dapat menyebabkan hal ini yaitu penghasilan keluarga $\geq$ UMR sehingga memiliki asupan nutrisi yang cukup baik untuk mendukung pertumbuhan anak termasuk tinggi badan. Pendapatan keluarga yang memadai akan menunjang tumbuh kembang anak, karena responden dapat menyediakan semua kebutuhan anak, baik primer maupun sekunder (Putra, 2016). Kondisi sosial ekonomi juga berkaitan dengan terjadinya stunting. Keluarga dengan pendapatan yang relatif rendah akan mengalami kesulitan memenuhi kebutuhan nutrisi. Situasi ini biasanya terjadi pada balita dari keluarga dengan penghasilan rendah (Pacheco et al., 2017). Balita yang berasal dari keluarga dengan status ekonomi rendah lebih banyak mengalami stunting dibandingkan balita dari keluarga status ekonomi tinggi (Putra, 2016). Berdasarkan hasil penelitian yang diperoleh di Kecamatan Buntu Malangka penghasilan keluarga $\geq$ UMR lebih banyak pada kelompok kontrol dibandingkan kelompok kasus yaitu sebanyak 9 (12.5\%) responden. Kemudian faktor tidak langsung lain yaitu kunjungan ANC selama kehamilan yang dilakukan oleh ibu secara teratur dapat mendeteksi dini risiko kehamilan terutama yang berkaitan dengan masalah nutrisinya (Soesanto \& Winaryati, 2009). Berdasarkan hasil penelitian yang diperoleh di Kecamatan Buntu Malangka riwayat ANC yang $\geq 3$ kali pada kelompok kontrol lebih besar dari kelompok kasus yaitu sebanyak 60 (83.3\%) responden. Faktor tidak langsung selanjutnya ialah riwayat imunisasi. Imunisasi adalah suatu cara untuk memberikan kekebalan terhadap seseorang secara aktif terhadap penyakit menular. Imunisasi adalah suatu cara untuk meningkatkan kesehatan seseorang secara aktif terhadap suatu antigen, sehingga bila kelak ia terpapar antigen yang serupa tidak pernah terjadi penyakit (Kemenkes, 2016). Berdasarkan hasil penelitian yang diperoleh di Kecamatan Buntu Malangka, balita yang mendapatkan imunisasi lengkap lebih banyak pada kelompok kontrol yaitu sebanyak 68 (94.4\%) responden.

Hasil penelitian juga menunjukkan terdapat balita yang diberi ASI eksklusif dan mengalami stunting sebanyak $6(8.3 \%)$ responden. Stunting disebabkan oleh faktor multi dimensi dan tidak hanya disebabkan oleh faktor gizi buruk yang dialami oleh ibu hamil maupun anak balita. Beberapa faktor yang menjadi penyebab stunting dapat digambarkan yaitu situasi ibu/calon ibu, situasi balita, situasi sosial ekonomi dan situasi sanitasi dan akses air minum (Kemenkes, 2018c). Salah satu faktor dalam situasi balita yaitu BBLR. Menurut Putra (2016) BBLR yaitu berat badan bayi lahir kurang dari 2500 gram. BBLR erat kaitannya dengan mortalitas dan mordibitas janin. Keadaan ini dapat menghambat pertumbuhan dan perkembangan kognitif, kerentanan terhadap penyakit kronis di kemudian hari. Pada tingkat populasi, proporsi bayi dengan BBLR adalah gambaran multi masalah kesehatan masyarakat mencakup ibu yang kekurangan gizi jangka panjang, 
kesehatan yang buruk, perawatan kesehatan dan kehamilan yang buruk. Hal ini berhubungan dengan risiko tinggi pada kematian bayi dan anak. Berdasarkan penelitian ini didapatkan berat badan balita saat lahir < 2500 gram lebih banyak pada kelompok kasus dibandingkan kelompok kontrol yaitu sebanyak 14 (19.4\%) responden. Faktor tidak langsung lain yaitu tingkat pendapatan, dari hasil penelitian yang didapatkan di Kecamatan Buntu Malangka tingkat pendapatan keluarga < UMR terbanyak pada kelompok kasus yaitu sebanyak 67 (93.1\%) responden. Keluarga dengan pendapatan yang relatif rendah akan mengalami kesulitan memenuhi kebutuhan nutrisi. Situasi ini biasanya terjadi pada balita dari keluarga dengan penghasilan rendah (Pacheco et al., 2017).

Berdasarkan hasil penelitian yang diperoleh terdapat 61 (84.7\%) balita yang diberikan ASI eksklusif dan non-stunting. Menurut Mufdlilah (2017) ASI adalah air susu yang dihasilkan oleh ibu dan mengandung semua zat gizi yang diperlukan oleh bayi untuk kebutuhan pertumbuhan dan perkembangan bayi. ASI eksklusif adalah bayi hanya diberi ASI saja, tanpa tambahan cairan lain seperti susu formula, air jeruk, madu, air teh, air putih dan tanpa tambahan makanan padat seperti pisang, pepaya, bubur susu, biskuit, bubur nasi dan tim, selama 6 bulan. Menurut Kusumayanti \& Nindya (2017) bayi yang mendapatkan ASI eksklusif merupakan bayi yang hanya menerima ASI saja sehingga tidak ada cairan atau padatan lainnya diberikan, bahkan air dengan pengecualian rehidrasi oral, atau tetes/sirup vitamin, mineral atau obat-obatan. United Nation Childrens Fund (UNICEF) dan World Health Organization (WHO) merekomendasikan sebaiknya anak hanya disusui air susu ibu (ASI) selama paling sedikit enam bulan. Makanan padat seharusnya diberikan sesudah anak berusia 6 bulan, dan pemberian ASI dilanjutkan sampai anak berusia dua tahun. Menurut Indrawati (2016) Keberhasilan ASI secara eksklusif dapat dipengaruhi oleh faktor seperti status pekerjaan. Ibu yang tidak bekerja, akan memiliki banyak waktu untuk merawat bayinya termasuk memberikan ASI Eksklusif. Hasil penelitian menunjukkan dari 144 responden, jumlah terbanyak responden yang tidak bekerja/IRT berada pada kelompok kontrol yaitu sebanyak 35 (48.6\%) responden.

Locitasari (2015) menyatakan bayi yang mendapat susu formula memiliki risiko 5 kali lebih besar mengalami pertumbuhan yang tidak baik pada bayi usia 0-6 bulan dibandingkan dengan bayi yang mendapat ASI. Indrawati (2016) menyatakan bahwa ASI merupakan asupan gizi yang sesuai dengan kebutuhan akan membantu pertumbuhan dan perkembangan anak. Bayi yang tidak mendapatkan ASI dengan cukup berarti memiliki asupan gizi yang kurang baik dan dapat menyebabkan kekurangan gizi. Berdasarkan kenyataan yang ada dilapangan dari total 144 responden, pada kelompok kasus jumlah responden yang memberikan ASI eksklusif sebanyak 6 (8.3\%) responden sedangkan pada kelompok kontrol, jumlah responden yang memberikan ASI eksklusif sebanyak 61 $(84.7 \%)$ responden.

\section{Kesimpulan dan Saran}

Berdasarkan hasil penelitian ada hubungan pemberian ASI eksklusif dengan kejadian stunting pada balita. Sedangkan pada uji odds ratio didapatkan nilai OR = 61 yang artinya balita yang tidak diberikan ASI eksklusif berpeluang 61 kali lipat mengalami stunting dibandingkan balita yang diberi ASI eksklusif. ASI eksklusif dapat mengurai risiko terjadinya stunting. 


\section{Daftar Rujukan}

Dahlan, M. S. (2014). Statistik Untuk Kedokteran dan Kesehatan (Edisi 6). Jakarta: Epidemiologi Indonesia.

Diaz, Y., Lusmilasari, L., \& Madyaningrum, E. (2017). Fenomena Perilaku Makan Toddler dan Hubungannya dengan Perilaku Pemberian Makan Orang Tua. Journals of Ners Community, 8, 159-171.

F.B.Monika. (2014). Buku Pintar Asi dan Menyusui. Jakarta Selatan: Penerbit Noura Books.

Fitri, L. (2018). Hubungan BBLR dan ASI eksklusif dengan kejadian stunting di Puskesmas Lima Puluh Pekanbaru. Jurnal Endurance, 3(1), 131-137. Retrieved from http://doi.org/10.22216/jen.v3i1.1767

Fitriahadi, E. (2018). Hubungan tinggi badan ibu dengan kejadian stunting pada balita usia $24-59$ bulan The relationship between mother' s height with stunting incidence in children aged 24-59 months, 14(1), 15-24.

Indrawati, S., \& Warsiti. (2016). Hubungan pemberian ASI eksklusif dengan kejadian stunting pada anak usia 2-3 tahun di Desa Karangrejek Wonosari Gunungkidul.

Karyani, I., Husin, S., \& Febry, F. (2012). Gambaran Kebiasaan Makan pada Anak PraSekolah di TK Bhakti Asuhan dan TKIT Izzuddin Palembang Tahun 2009. Jurnal Ilmu Kesehatan Masyarakat, 3, 182-193.

Kemendesa. (2017). Buku Saku Desa dalam Penanganan Stunting. Jakarta: Kemendesa RI.

Kemenkes. (2010). Standar Antropometri Penilaian Status Gizi Anak. Kemenkes RI.

Kemenkes. (2014). Infodatin (Situasi dan Analisis ASI Eksklusif). Jakarta: Kemenkes RI Pusat Data dan Informasi.

Kemenkes. (2016). Situasi Balita Pendek. Jakarta Selatan: Kemenkes RI Pusat Data dan Informasi.

Kemenkes. (2018a). Cegah Stunting itu Penting. Jakarta: Kemenkes RI.

Kemenkes. (2018b). Hasil Utama Riskesdas 2018. Jakarta.

Kemenkes. (2018c). Situasi Balita Pendek (Stunting) di Indonesia. Jakarta Selatan: Kemenkes RI Pusat Data dan Informasi.

Khamzah, S. N. (2012). Segudang Keajaiban ASI yang Harus Anda Ketahui. (D. Toanto, Ed.). Jogjakarta: FlashBooks.

Khasanah, N. (2011). ASI atau Susu Formula Ya? (N. Sawitri, Ed.). Jogjakarta: FlashBooks.

Kusumayanti, N., \& Nindya, T. S. (2017). Hubungan dukungan suami dengan pemberian asi eksklusif di daerah perdesaan. Media Gizi Indonesia, 12(2), 98-106.

Locitasari, Y. (2015). Perbedaan Pertumbuhan Bayi Usia 0-6 Bulan yang Diberi ASI Eksklusif dengan yang Diberi Susu Formula di Kecamatan Ngawi. Skripsi.

Lusiana, N., Andriyani, R., \& Megasari, M. (2015). Buku Ajar Metodologi Penelitian. Yogyakarta: Deepublish.

Manggala, A. K., Kenwa, K. W. M., Kenwa, M. M. L., Sakti, A. A. G. D. P. J., \& Sawitri, A. A. S. (2018). Risk Factors of Stunting in Children Aged 24-59 Months. Paediatrica Indonesiana, 58(5), 205-212. Retrieved from

http://dx.doi.org/10.14238/pi58.5.2018.205-12 Original

Millenium Challengga Account Indonesia. (2013). Stunting dan Masa Depan Indonesia, 2010, 2-5.

Mufdlilah. (2017). Buku Pedoman Pemberdayaan Ibu Menyusui pada Program ASI Eksklusif. Yogyakarta.

Mulyani, N. S. (2013). ASI dan Panduan Ibu Menyusui. Yogyakarta: Nuha Medika.

Ni'mah, K., \& Nadhiroh, S. R. (2015). Faktor yang Berhubungan dengan Kejadian Stunting pada Balita. Media Gizi Indonesia, 10(1), 13-19.

Nirwana, A. B. (2014). ASI dan Susu Formula: Kandungan dan Manfaat ASI dan Susu Formula. Yogyakarta: Nuha Medika. 
Pacheco, C. do R., Picauly, I., \& Sinaga, M. (2017). Health, Food Consumption, Social Economy, and Stunting Incidency in Timor Leste. Jurnal Kesehatan Masyarakat, 13(2), 261-269. Retrieved from http://journal.unnes.ac.id/nju/index.php/kemas\%0AHEALTH,

Paschalia, Yustina, P. . (n.d.). Analisis Faktor-faktor yang mempengaruhi pemberian ASI eksklusif pada bayi di Puskesmas Rewarangga, 141-152.

Putra, O. (2016). Pengaruh BBLR terhadap kejadian stunting pada anak usia 12-60 bulan di Wilayah Kerja Puskesmas Pauh pada tahun 2015. Universitas Andalas.

Ratu, N. C., Punuh, M. I., \& Malonda, N. S. H. (n.d.). Hubungan Tinggi Badan Orangtua dengan Kejadian Stunting pada Anak Usia 24-59 bulan di Kecamatan Ratahan kabupaten Minahasa Tenggara. Kesmas, 7(4).

Rohmatun, N. (2014). Hubungan tingkat pendidikan ibu dan pemberian asi eksklusif dengan kejadian stunting pada balita di Desa Sidowarno Kecamatan Wonosari Kabupaten Klaten.

Septiani, H., Artha, B., \& Karbita. (2017). Faktor-Faktor yang Berhubungan dengan Pemberian ASI Eksklusif Oleh Ibu Menyusui yang Bekerja Sebagai Tenaga Kesehatan, 2(2), 159-174. Retrieved from http://ejournal.stikesaisyah.ac.id/index.php/jika/

Soesanto, E., \& Winaryati, E. (2009). Ante Natal Care (ANC) dalam reprektif ibu hamil: gambaran kerentanan kesehatan reproduksi pada masyarakat nelayan di Kabupaten Rembang. Jurnal Keperawatan, 2(2), 21-27.

Soetjiningsih, \& Ranuh, G. (2013). Tumbuh Kembang Anak (2nd ed.). Jakarta: EGC.

TNP2K. (2017). 100 Kabupaten/Kota Prioritas Untuk Intervensi Anak Kerdil (Stunting). Tim Nasional Percepatan Penanggulangan Kemiskinan.

Yusrina, A., \& Devy, S. R. (2016). Faktor yang mempengaruhi niat ibu memberikan ASI eksklusif di Kelurahan Magersari, Sidoarjo. Jurnal Promkes, 4, No.1, 11-21 